Journal of Engineering and Applied Sciences 14 (Special Issue 9): 10534-10537, 2019

ISSN: 1816-949X

(C) Medwell Journals, 2019

\title{
Competency-Based Employer's Model: Some Consequences of Demilitarization in the National School System
}

\author{
${ }^{1}$ Hana Tomaskova and ${ }^{2}$ Bohuslav Pernica \\ ${ }^{1}$ Faculty of Infomatics and Management, University of Hradec Kralove, \\ Rokitanského 62, 50003, Hradec Králové, Czech Republic \\ ${ }^{2}$ Institute for Regional and Security Sciences, Faculty of Economics and Administration, \\ University of Pardubice, Studentská 84, 53210 Pardubice, Czech Republic
}

\begin{abstract}
The study focuses on competency-based employer's model and extends it by using a systemic approach to modeling. The models are focused on the inability of the system to refill the declining competence of the earliest stages of development and indicates future problems in specialized systems.
\end{abstract}

Key words: Competency-based employer’s model, modeling, system, dynamic, specialized, earliest

\section{INTRODUCTION}

The end of the cold war and the end of communism in Czechoslovakia and the Czech Republic a brought not only a significant downsizing of the military but it caused a mass demilitarization of national economy (Popper, 1991; Szayna, 1992) and demilitarization in the national school system. Taking into account that the compulsory military education on both elementary, secondary schools and universities was abolished in the mid of 1991 an effective system of military pre-training (formal aimed on education in the civil defence) not only come to an end but institutional capabilities (Svazarm) providing real military pre-training to conscripts in the span between their military draft act and their call-up into compulsory military service dissolved as well (Szayna and Steinberg, 1992). Moreover, the phenomenon of mass conscription society which polity was constituted by combining ideology and military-bureaucratic organization (Kazsa, 1995), disappeared as well although such a peculiar mixture induced not only into armed forces but into national economy manpower with a set of really employer-friendly competences such reliability, discipline, endurance, stress resistance, ability of working independently and in a team, respect for authorities and so on (Alexiev et al., 1986). In brief, the militarized national school system might contribute to vocational professionalism (Sorensen, 1994) in general.

The aim of that contribution is to present a competency-based model employer's model in the nexus with the all-volunteer force in the Czech Republic. Researcher would like to explain some deficiencies in the national labour market as a consequence of excessive demilitarization of the Czech society.
Competency-based model: Competency-based model is a tool that describes and identifies the skills needed for operating in specific role. C-B Model is a behavioral description (definition) for any individual job roles and each job (Fogg, 1999). In the study of Rothwell (2002) was explained the core of competencies that are required for all workers.

Upbringing and vocational pre-training means the process of obtaining knowledge, acquiring skills, attitudes and competences from everyday experience and activities at work, family and leisure time. It also includes self-education but the individual is not able to verify the acquired knowledge. An important educational environments such as families, schools and other educational facilities are also firm or organization and its control processes.

\section{MATERIALS AND METHODS}

Competence-based employer's model: The rise of modern armed forces after French Revolution did not only bring the phenomena of conscription and mass armed forces but a closer focus on civil-military relation as well. The military power got a part of society because not only privileged nobles might get officers and generals but every man who proved his competencies to be a military commander. Armed forces of that time did not differ in their strength and equipment rather in military professionalism their personal (Huntigton, 1957). Therefore, it might not be considered as a surprise that academics introduced the topic of military competencies into scientific journals. In particular, the discussion was hold about competencies of officers and especially Prussian contributors, e.g., Volz ware very supportive indeed to the idea of integration military 


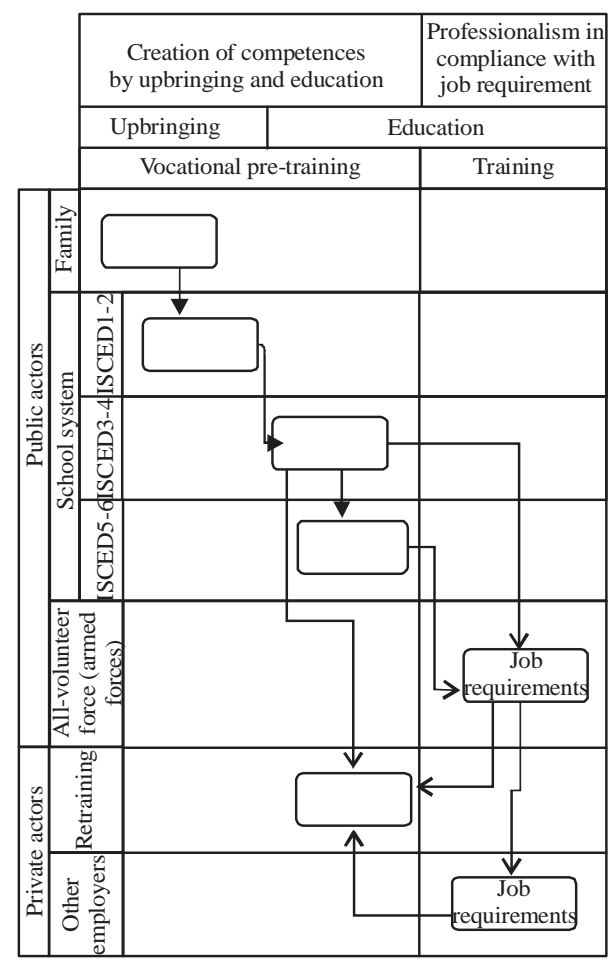

Fig. 1: Competence-based employer’s model

training into academic education in order to establish compulsory military pre-training able to select genuine military leader.

That should be beneficial for armed forces from many points of view. Firstly, the selection of military leaders should take place from a more substantial, homogenous and representative population cohort than the male population joining the military was. Secondly, the selection might take much longer time than military service of that time lasted. Last but not least, study at a university was a natural filter referring to man's intelligence his will and motivation. In fact, broadly accepted military job requirements determined functionality of school system and affected the upbringing of men in families. In essence that approach continues on. Nevertheless such Institution/Occupational Model (I/O model) got its importance by the end of conscription and the shift to All-Volunteer Force (AVF). Also, a universal competence-based employer's model could be developed as presented in Fig. 1.

Taking into account theory of I/O Model (Sorensen, 1994; Janowitz, 1977; Moskos, 1977), some competencies are difficult to form after reaching some specific age because he/she might be already not educable. For instance if she/he got some addiction or she/he was brought up as only child in addition an individualist. Then it might be difficult to train him/her to team work and to subordinate his/her personality to esprit de corps. From such a point of view, we should admit that demographic, social and economic changes affect not only the military capabilities but the entire labour market. In particular if the family and school system surrendered of provide competencies comprising moral and ethics.

In addition, we selected some competencies stressed in laws introducing physical education, paramilitary training and training in civilian defence into Czechoslovak schools which ought to be formed in students during their compulsory education and which might be found useful for labour market:

- Physical education: strength, endurance, hardiness, strength of will competitiveness, team cohesion, dignity

- Paramilitary training: civic pride, discipline, ability to organize, rejection of extremism, courage, mental resilience, respect to rules and law

- Training in civilian defence: circumspection, patience, perception of others, risk rating, adaptation to insecurity

\section{RESULTS AND DISCUSSION}

Dynamic of competence-based employer's model: System dynamics was presented by Forrester as a technique for demonstrating and analysing the behaviour of complex social systems, especially in a mechanical setting. It has been utilized to look at different social, economical and ecological frameworks (Wolstenholme, 1990) where an all encompassing perspective is important and input circles are basic to understanding the interrelationships. The main diagrams used for system dynamic modeling are "Causal Loop Diagram" and "Stock and Flow Diagram".

Causal Loop diagram explains the behavior of a system by showing a collection of connected nodes and the feedback loops created by the connections. Causal loop diagram consists of a plurality of nodes representing variables and a plurality of arrows showing the relationships between them (Anderson and Johnson, 1997). Each arrow in a CLD is labeled with a minus or plus sign. The minus sign denotes that the first variable causes a change in the opposite direction in the second variable. A plus sign is used to signify that a change in one variable causes the second variable to change in the same direction, relationship is exponential. Arrows form loops and each loop is indicated by R or B. R means reinforcing and $\mathrm{B}$ means balancing.

Figure 2 shows a simple causal relationship of competencies that's are given or required by family, school systems or employers. Competence transmitted by family are empowered by competences acquired within the school system. The school system can transmit sufficient competences required and extensible in All 
volunteer force. The missing competencies from school system have to be added during the retraining. By this case is the relationship signed as "minus" and it is contained in the balancing cycles.

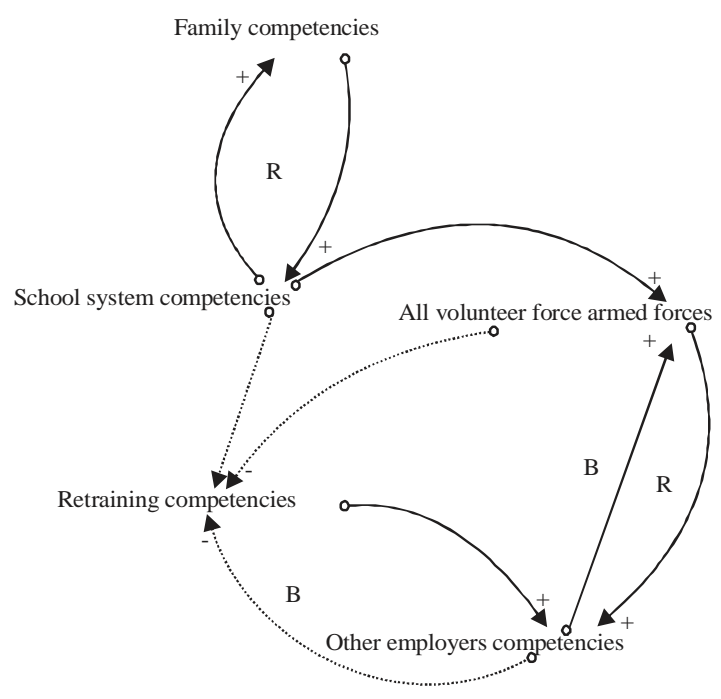

Fig. 2: Causal loop diagram
Second, we have compiled a blind model with basic elements. The model is made up according to system dynamics approach, especially, the STELLA Software 16, where there are the basic elements "Stock, Flow, Converter and Connector" (Wolstenholme, 1990).

Stocks, the rectangle has four varieties: reservoirs, conveyors, queues and oven. The most frequently used type of stock is the reservoir. The stock represents the main quantity that is to be accumulated (e.g., population, money in bank account, etc). The value increases or decreases over time.

Flows, the arrows have three varieties: a uniflow, a bif low and a unit converted flow. Flow represents activities that cause the stock value to increase or decrease. Consverters, the circle, represents a rates or relationships. A converter is used to represent additional logic important to the model. It is often a modiffer for the flow. Connector serves either as an information wire or as an action wire.

In Fig. 3 are united the relationships from Fig. 1 and 2 in an angle of system dynamics. Competencies are "stored" in the corresponding stocks. Inflows into the corresponding stocks are affected by adequate effects in relevant converters.

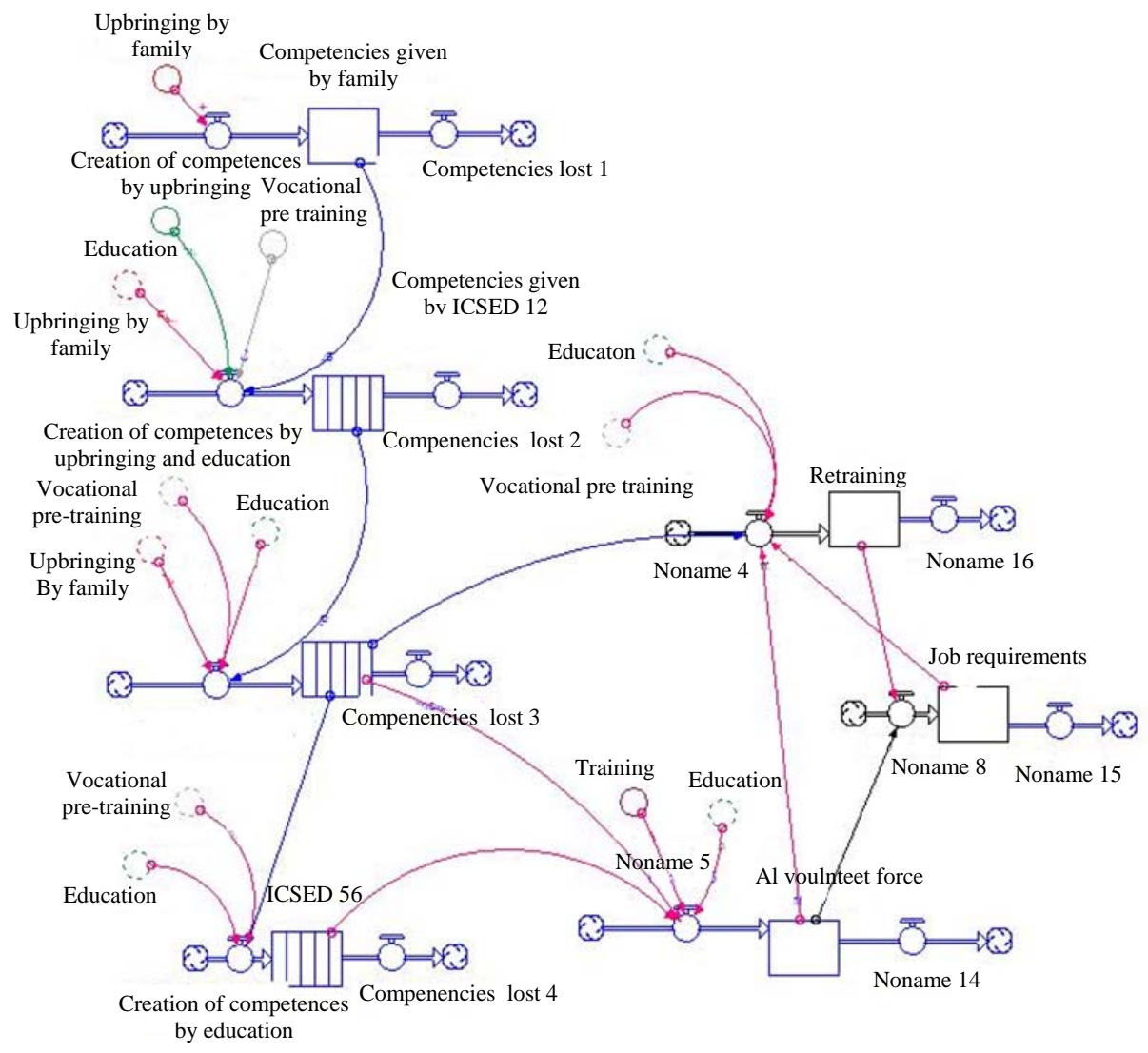

Fig. 3: Stock and flow diagram 


\section{CONCLUSION}

If the gain competencies that family and the school system are inadequate, then the resulting lack is exponentially magnified in the next stage. The only sources of additional competencies are contained in the Retraining of balance cycles. Given that the "Armed Forces" are primarily stocked with "competence" after school systems are primarily affected by a possible impairment. Retrainig competencies into the reporting system can get up after the passage of another node "other Employers". The transversal nature of key competences makes them essential. They provide added value for employment, social cohesion or young people.

\section{ACKNOWLEDGEMENTS}

The support of Czech Science Foundation GAČR $\# 14-02424 S$ and the Student specific grant project is gratefully acknowledged.

\section{REFERENCES}

Alexiev, A., A.R. Johnson and B.A. Kliszewski, 1986. East European Military Reliability an Emigre-Based Assessment. RAND Corporation, Santa Monica, California,.

Anderson, V. and L. Johnson, 1997. Systems Thinking Basics. Pegasus Communications, Cambridge, Massachusetts,.

Fogg, C.D., 1999. Implementing your strategic plan: How to turn intent into effective action for sustainable change. American Management Association, New York, USA.
Huntigton, S.P., 1957. The Soldier and the State: The Theory and Politics of Civil-Military Relations. Belknap Press, Cambridge, Mass, Pages: 534.

Janowitz, M., 1977. From institutional to occupational: The need for conceptual continuity. Armed Forces Soc., 4: 51-54.

Kazsa, G.J., 1995. The Conscription Society: Administered Mass Organization. Yale University Press, London, England,.

Moskos, J.C.C., 1977. From institution to occupation: Trends in military organization. Armed Forces Soc., 4: 41-50.

Popper, S.W., 1991. Conversion of Arms Industries in Central Europe. RAND Corporation, Santa Monica, California, ISBN:0-8330-1949-X,.

Rothwell, W.J., 2002. The workplace learner: How to align training initiatives with individual learning competencies. AMACOM, New York, USA., ISBN:0-8144-0674-2, Pages: 357.

Sorensen, H., 1994. New perspectives on the military profession: The I/O model and esprit de Corps reevaluated. Armed Forces Soc., 20: 599-617.

Szayna, T.Z. and J.B. Steinberg, 1992. Civil-Military Relations and National Security Thinking in Czechoslovakia. RAND Corporation, Santa Monica, California,.

Szayna, T.Z., 1992. The Military in a Postcommunist Czechoslovakia. RAND Corporation, Santa Monica, California,.

Wolstenholme, E.F., 1990. System Enquiry-A System Dynamics Approach. John Wiley and Sons, New Yor, USA., ISBN:0-471-92783-X,. 